\title{
Audio Visual-Based Learning on Landslide and Tsunami Mitigation in Fifth Grade Students at State Primary School (SDN) 6 Mataram
}

\author{
Kosim Kosim* \\ Physics Education Study Program \\ Universitas Mataram \\ Mataram, Indonesia \\ $\underline{\text { kosim_fisika@unram.ac.id }}$ \\ Syahrial.A \\ Physics Education Study Program \\ Universitas Mataram \\ Mataram, Indonesia
}

\author{
Wayan Gunada \\ Physics Education Study Program \\ Universitas Mataram \\ Mataram, Indonesia \\ Endang P. Handayani \\ State Primary School 6 Mataram \\ Mataram, Indonesia
}

\begin{abstract}
This study aims to examine whether the learning methods that have been used are appropriate to teach about natural disaster mitigation. Audio visual based learning method was being used to discuss learning materials about landslide and tsunami. The research subjects were students of State Primary School (SDN) 6 Mataram. Based on the F-test two-way variance with a significant level $\alpha=5 \%$, it is shown that Ho is accepted, which means that there is no difference in the cognitive achievement of landslide and tsunami teaching materials as the application of audio visual-based mitigation learning models in fifth grade students of State Primary School (SDN) 6 Mataram. It can be concluded that the use audio visual - based learning method for teaching disaster mitigation can be applied to elementary students.
\end{abstract}

Keywords - natural disaster mitigation, audio-visual method, landslide, tsunami

\section{INTRODUCTION}

Lombok is one of the areas declared as vulnerable to natural hazards such as earthquakes, tsunamis, floods and landslides. Based on the experience from the earthquakes that occurred on Lombok in 2018, all components of the nation realized the importance of disaster mitigation. Disasters cannot be expected, but humans must try to mitigate as an act of reducing the risk of disaster. Mitigation needs to be done early, especially in elementary school students.

The curriculum on disaster mitigation in elementary schools does not appear clearly, but the material relating to environmental problems also involves the problem of disaster and its prevention. Disaster issues discussed in this study focus on landslide and flood disasters.

Problems that arise, how to teach disaster mitigation to elementary students so that the minimum ability of knowledge about it can be achieved. Through many of literatures, the learning method for audio-visual based mitigation becomes the choice to be applied and needs statistical proof that the method is relevant to be applied. The research subjects were students of fifth grade atS Primary School (SDN) 6 Mataram, as well as working partners in this study.
The formulation of the problem presented is in what extent the application of an audio-visual based mitigation learning model for $5^{\text {th }}$ grade students at SDN 6 Mataram is appropriate for landslide and tsunami teaching materials?. Research hypotheses have been created to answer the formulation of the problem which are:

$\mathrm{H}_{0}$ : There is no difference in the variance of cognitive achievement in landslide and tsunami teaching materials as audio visual based mitigation learning model was applied for $5^{\text {th }}$ grade students of SDN 6 Mataram

$\mathrm{H}_{\mathrm{A}}$ : there is a difference in the variance of cognitive achievement in landslide and tsunami teaching materials as audio visual based mitigation learning models was applied for 5th grade students of SDN 6 Mataram

\section{RESEARCH METHOD}

Research subjects were $5^{\text {th }}$ grade students of SDN 6 Mataram with a total of 39 students. There are two learning materials: Landslide and tsunami, each of it lasting for about 2 hours of study on different days. Class situations and conditions are prepared with audio-visual equipment such as computers, LCDs, microphones and speakers. Data gathering is done after learning is complete. Students were asked to fill in the answer sheet while paying attention to the slide show and audio visual presentation. $=5 \%$.

Hypothesis testing has been used two-way $\mathrm{F}$ test with $\alpha$ 


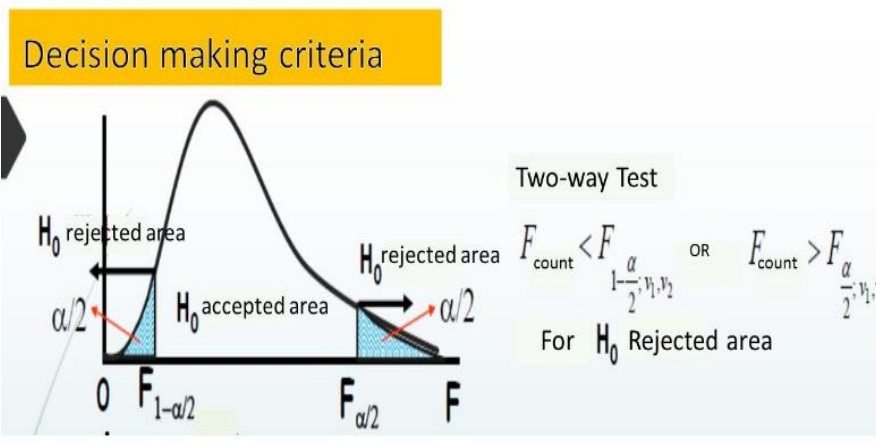

Johnson, R.A., Bhattacharyya, G.K. (1996)

\section{RESULTS AND DISCUSSION}

\section{A. RESULTS}

Cognitive outcomes of $5^{\text {th }}$ grade students in SDN 6 Mataram in learning to mitigate tsunami and landslides based on audio-visual are shown in Table 1. It can be seen that the percentage of students' cognitive in study of landslide material is fewer than the percentage of that of tsunami material. It is suspected that students are not familiar using audio-visual in learning process, so it needs to be adjusted. However, in the next learning stage with the similar method, students seemed to be relaxed and more comfortable in adjusting the new method in learning activities.

TABLE 1. STUDENT COGNITIVE ACHIEVEMENTS IN DISASTER MITIGATION LEARNING

\begin{tabular}{|l|l|l|}
\hline & $\begin{array}{l}\text { Students' } \\
\text { achievement in } \\
\text { landslide material }\end{array}$ & $\begin{array}{l}\text { Students' } \\
\text { achievement in } \\
\text { tsunami material }\end{array}$ \\
\hline Average score & 78,3 & 88,0 \\
\hline Variance $\left(\mathrm{S}^{2}\right)$ & 70,35 & 87,97 \\
\hline $\begin{array}{l}\text { Standard } \\
\text { Deviation (S) }\end{array}$ & 8,39 & 9,38 \\
\hline \% score up to 75 & $64,1 \%$ & $82,1 \%$ \\
\hline
\end{tabular}

The two-way $\mathrm{F}$ test calculation results with the calculated formula $F=\left(S \_1 \wedge 2\right) /\left(S \_2 \wedge 2\right)$ and $F=\left(S \_2 \wedge\right.$ $2) /\left(S \_1 \wedge 2\right)$ and $F$ tables as references with the criteria $F$ $(0.05)(\mathrm{n} 1-1)(\mathrm{n} 2-1)$ to test the hypothesis is shown in Table 2 below.

TABEL 2. RESULT OF F TWO-WAY TEST

\begin{tabular}{|c|c|c|}
\hline F value & $F=\frac{s_{1}^{2}}{s_{2}^{2}}=0,7997$ & $\begin{array}{c}F=\frac{s_{2}^{2}}{s_{1}^{2}}= \\
\mathbf{1 , 2 5 0 5}\end{array}$ \\
\hline $\begin{array}{l}\mathrm{F}_{\text {table }} \text { ( two-way) } \alpha=0,05, \mathrm{v} 1 \\
=38 ; \mathrm{v} 2=38 \\
\text { (Because in the table, position } \\
\text { of } \mathrm{v} 1 \text { and } \mathrm{v} 2 \text { are at numbers } 30 \\
\text { and } 40, \text { they are taken to the }\end{array}$ & $\begin{array}{l}\mathrm{F}_{(1-\alpha / 2), \mathrm{v} 1 ; \mathrm{v} 2}= \\
0,5319\end{array}$ & $\begin{array}{l}\mathrm{F}_{(\alpha / 2), \mathrm{v} 1 ; \mathrm{v} 2}= \\
1,88\end{array}$ \\
\hline
\end{tabular}

closest numbers, v1 and v2 at number 40)

Based on the results of Table 2 and referring to the hypothesis testing criteria, it showed that the $\mathrm{F}$ test results are in the accepted of Ho position. These results indicated that there is no difference in the cognitive achievement variance of landslide and tsunami teaching materials as the application of audio visual based mitigation learning models in $5^{\text {th }}$ grade students of SDN 6 Mataram.

\section{B. DISCUSSION}

Learning activities for audio visual- based natural disaster mitigation, as it can be seen in Table 3 , adapted from the learning syntax for natural disaster mitigation [1]. The difference between the syntax learning activities in Table 3 and the syntax presented [1] is in the core activities by providing field evacuation practices. Whereas, in the audio-visual approach, the full core activities of students are observing, both in terms of the senses of sight and hearing through impressions in the form of short cartoon films about mitigation, as well as slides from power points about the similar topics. Besides, the process of discussion between and from students to teachers is provided by means of the short film, then students will guess/discuss approximately what will happen next. Slideshows were used in this activity. The main target in this study is to provide information on the understanding of disaster mitigation.

TABLE 3. LEARNING LOCATIONS FOR AUDIO-VISUAL-BASED NATURAL DISASTER MITIGATION

\begin{tabular}{|c|c|c|}
\hline $\begin{array}{c}\text { Main } \\
\text { activity }\end{array}$ & Step & Aim \\
\hline \multirow[t]{2}{*}{$\begin{array}{l}\text { Opening } \\
\text { activity }\end{array}$} & $\begin{array}{l}\text { Introduction } \\
\text { 1. Watching natural } \\
\text { disaster and their } \\
\text { causes. }\end{array}$ & $\begin{array}{l}\text { Provide awareness that natural } \\
\text { disasters exist around us and } \\
\text { cause danger (damage to } \\
\text { housing, bodily accidents, } \\
\text { famine, trauma, disasters, and } \\
\text { can even cause death). }\end{array}$ \\
\hline & $\begin{array}{ll}\text { 2. } & \text { Giving } \\
\text { motivation and } \\
\text { appreciation }\end{array}$ & $\begin{array}{l}\text { Discuss a little about natural } \\
\text { disaster films and topics related } \\
\text { to disaster that have been } \\
\text { shown. }\end{array}$ \\
\hline \multirow[t]{2}{*}{$\begin{array}{l}\text { Main } \\
\text { activity }\end{array}$} & $\begin{array}{l}\text { Formulation of } \\
\text { questions related to } \\
\text { the topic discussed. }\end{array}$ & $\begin{array}{l}\text { The teacher distributes LKPD } \\
\text { to each student that contains } \\
\text { questions related to the topic. }\end{array}$ \\
\hline & $\begin{array}{l}\text { Displaying audio- } \\
\text { visual with a short } \\
\text { film, interspersed with } \\
\text { Visual shows with } \\
\text { Power Point that } \\
\text { shows the existence of } \\
\text { mitigation activities } \\
\text { before the disaster, } \\
\text { when and after the } \\
\text { disaster occurred }\end{array}$ & $\begin{array}{l}\text { Students can answer questions } \\
\text { on the LKPD individually by } \\
\text { paying attention to Audio- } \\
\text { Visual materials and } \\
\text { information from the teacher } \\
\text { during the visual presentation, } \\
\text { students are allowed to ask, } \\
\text { except questions in the LKPD. } \\
\text { When this activity is } \\
\text { completed, then the students } \\
\text { need to complete the LKPD. }\end{array}$ \\
\hline $\begin{array}{l}\text { Closing } \\
\text { activity }\end{array}$ & Enrichment & $\begin{array}{l}\text { After the LKPD is collected, } \\
\text { the teacher deliver questions to } \\
\text { the students to remind the } \\
\text { material which have been } \\
\text { discussed. The teacher assigns }\end{array}$ \\
\hline
\end{tabular}




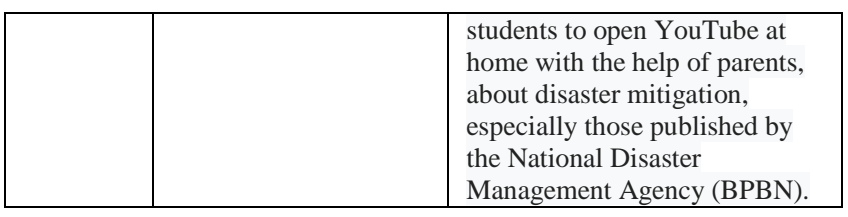

The word "landslide" which some of primary school students who are subjects of research are still unfamiliar. After showing at the beginning of the learning, students realize that the land collapsed or dropped. Landslides are a form of rock mass movement that can cause disaster for people who live in an area. Landslides often occur in slope or cliff areas [2]. Landslides can occur due to a strong earthquake or heavy rain that flush the slopes or cliffs. One example of landslides due to heavy rain in the cliff area in the village of Guntur Macan, Gunungsari district, West Lombok in 2015 due to heavy rainfall in the cliff area (Figure 1). Using comic illustrations (Figure 2), understanding of the dangers and causes of landslides easier for students to understand.

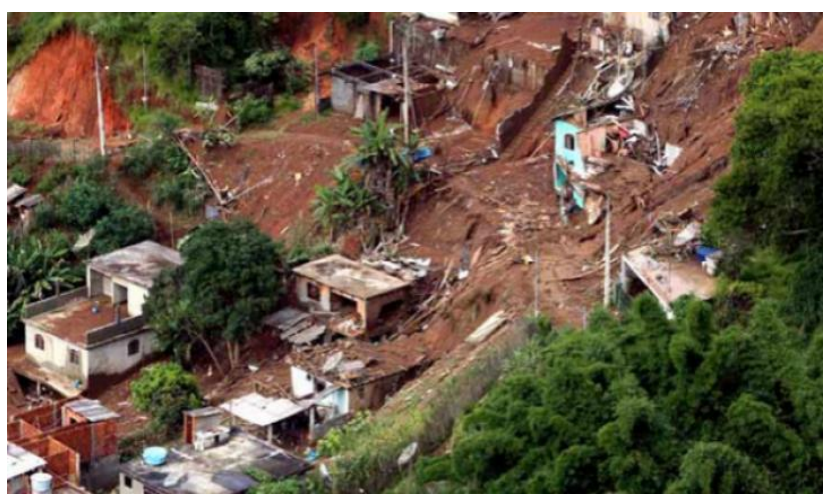

Fig. 1. landslide due to heavy rain in Guntur Macan Village (https://pesisirnews.com/Peristiwa/Korban-Tanah-Longsor-di-LombokBarat)

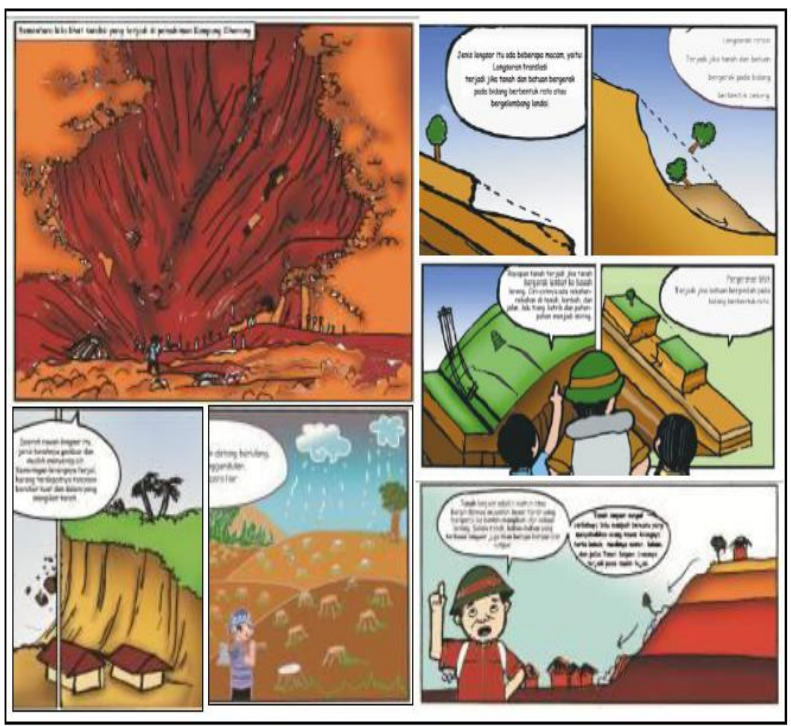

Fig. 2. Comic book about landslide(Yukni, 2011)

Likewise with the word "Tsunami", students need further explanation. They understood the meaning of tsunami after seeing the incident on a short film about the tsunami that occurred in Aceh in 2004. Tsunami events are better known as the result of earthquakes. One example of the impact of the Aceh tsunami is shown in Figure 3, which caused a huge devastation in the land of Aceh.

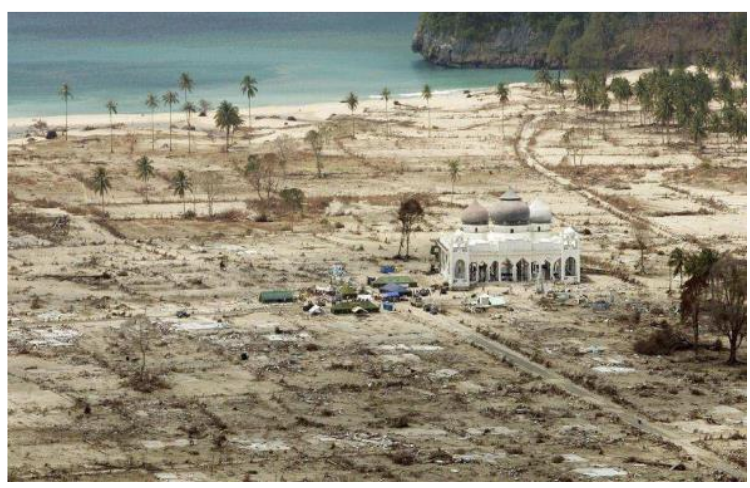

Fig. 3. The impact of Aceh's Tsunami in 2004

(https://www.thenational.ae/world/asia/how-indonesian-

mosquessurvived)

Tsunamis are large waves of sea water that rise to the mainland and cause disasters. Through Figure 4, it shown that students can discuss the signs of a tsunami and how to evacuate themselves.

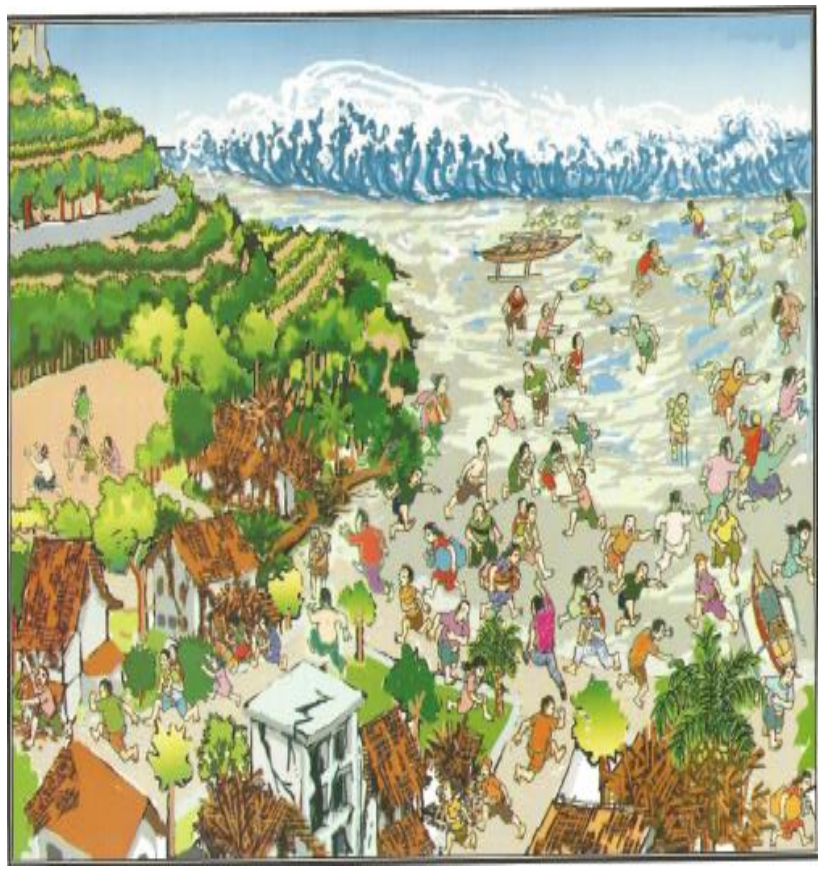

Fig. 4. Tsunami disaster

Learning efforts on disaster mitigation are widely introduced to students with various way such as comics[3], pop-up book[4], and presentation through video [5]. In fact, according to [6], motivation to study disaster mitigation in primary schools is an effort to form the character of students to be prepared to face natural disasters in the future event. Learning to mitigate natural disaster by using audio-visual that is continuously provided to students is expected to form awareness of preparedness in dealing with natural disasters.

Based on the results of the hypothesis: that the variance of students' scores on the material for the tsunami and landslide disasters by applying the mitigation learning 
model expressed in the syntax above, has shown relatively good learning outcomes. This means that the use of audiovisual based disaster mitigation learning models is indeed suitable to support teaching and learning materials particularly about natural disaster.

\section{CONCLUSION}

Based on the results of the research, it can be concluded that the application of audio-visual based mitigation learning model for $5^{\text {th }}$ grade students in SDN 6 Mataram is suitable for landslide and tsunami teaching materials.

\section{REFERENCES}

[1] S. Ayubi, Kosim, I. W. Gunada, and E. P. Handayani, "Pengembangan Model Pembelajaran Kesadaran Bencana Di Sekolah Dasar," J. Pijar Mipa, vol. 14, no. 2, pp. 68-73, 2019.

[2] S. Mulyaningsih, Pengantar Geologi Lingkungan. Yogyakarta.: Panduan, 2010.

[3] A. Yukni, Mengenal Lebih Dekat Tanah Longsor. Bandung: Pusat Vulkanologi dan Mitigasi Bencana Geologi, 2011.

[4] B. Wibowo, I. Vebrianti, N. R. Pertiwi, Y. Widiyatmoko, and M. Nursa'ban, "Disaster Mitigation pop up book sebagai media Pembelajaran Mitigasi berbasis Kearifan Lokal bagi Siswa Sekolah Dasar," J. Geomedia, vol. 15, 2017.

[5] H. Ulilrosyad, "Pengembangan Video Pembelajaran Kebencanaan Untuk Meningkatkan Kesiapsiagaan Menghadapi Bencana Banjir Pada Masyarakat Desa Wonosari Kecamatan Kebumen Kabupaten Kebumen," Skripsi, Universitas Negeri Semarang, 2015.

[6] D. Rizaldy, "Implementasi Mitigasi Bencana di Sekolah-Sekolah di Indonesia sebagai Upaya Pembentukan Karakter Siap Siaga," in PROSIDING PIT ke-5 Riset Kebencanaan IABI Universitas Andalas, 2018. 